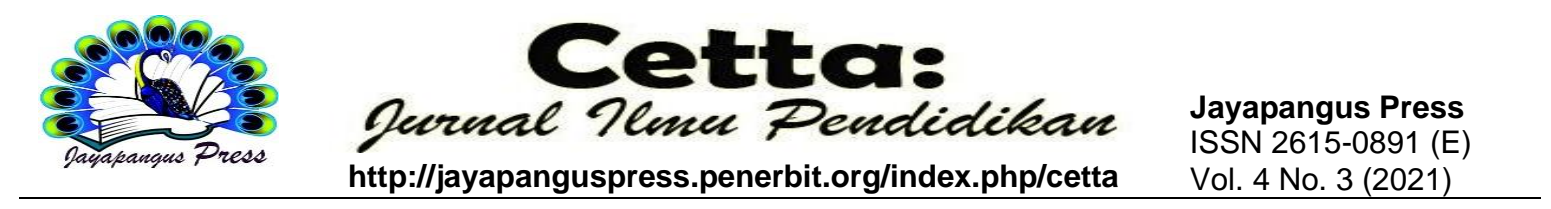

\title{
Penggunaan Metode Eksperimen Berbantuan Media Konkret Untuk Meningkatkan Hasil Belajar IPA Siswa Kelas IV SD Negeri 1 Seraya Barat
}

\author{
I Nengah Yusa Yusyana \\ SD Negeri 1 Seraya Barat \\ nengahyusa@gmail.com
}

\begin{tabular}{l}
\hline Keywords: \\
\hline Experimental \\
Method; \\
Concrete Media; \\
Learning \\
outcomes \\
\hline
\end{tabular}

\begin{abstract}
This study aims to improve the learning process by improving the science learning outcomes of fourth grade students of SD Negeri 1 Seraya Barat through the use of experimental methods assisted by concrete media. This classroom action research is designed in two cycles. Each cycle is carried out in four stages, namely: planning, implementation, evaluation, and reflection. The subjects of this study were fourth grade students of SD Negeri 1 Seraya Barat for the academic year 2019/2020 in the odd semester with a total of 32 students. The object of this research is the result of learning science on sound material. Science learning outcomes data were collected using the learning outcomes test. Data were collected using the test method. All data collected were analyzed descriptively. The criteria for the success of the action if the average student learning outcomes in science are at least 68 with classical mastery of at least $85 \%$. The results showed that the use of experimental methods assisted by concrete media could improve science learning outcomes for fourth grade students of SD Negeri 1 Seraya Barat in the odd semester of the 2019/2020 school year. This can be seen from the results of the data analysis of learning outcomes which reached 78.33 with a good category in the first cycle then in the second cycle it increased by 10.21 so that it became 88.54 with a very good category. In addition, learning mastery has increased by $31.25 \%$ from $65.63 \%$ to $96.88 \%$. Based on these results, it can be concluded that the use of experimental methods assisted by concrete media can improve science learning outcomes for fourth grade students of SD Negeri 1 Seraya Barat in the odd semester of the 2019/2020 school year.
\end{abstract}

Kata Kunci:

Metode

Eksprerimen;

Media Konkret;

Hasil Belajar

\begin{tabular}{l} 
Abstrak \\
\hline Penelitian ini bertujuan untuk memperbaiki proses pembelajaran \\
dengan jalan meningkatkan hasil belajar IPA Siswa Kelas IV SD \\
Negeri 1 Seraya Barat melalui penggunaan metode eksperimen \\
berbantuan media konkret. Penelitian tindakan kelas ini
\end{tabular}


dirancang dalam dua siklus. Setiap siklus dilaksanakan dalam empat tahapan yaitu: perencanaan, pelaksanaan, evaluasi, dan refleksi. Subjek penelitian ini adalah siswa kelas IV SD Negeri 1 Seraya Barat tahun pelajaran 2019/2020 pada semester ganjil dengan jumlah siswa sebanyak 32 orang. Objek penelitian ini adalah hasil belajar IPA pada materi bunyi. Data hasil belajar IPA dikumpulkan dengan menggunakan tes hasil belajar Data dikumpulkan dengan metode tes. Semua data yang terkumpul dianalisis secara deskriptif. Kriteria keberhasilan tindakan jika rata-rata hasil belajar IPA siswa minimal 68 dengan ketuntasan klasikal minimal 85\%. Hasil penelitian menunjukkan bahwa penggunaan metode eksperimen berbantuan media konkret dapat meningkatkan hasil belajar IPA siswa kelas IV SD Negeri 1 Seraya Barat semester ganjil tahun pelajaran 2019/2020. Ini terlihat dari hasil analisis data hasil belajar yang mencapai 78,33 dengan katagori baik pada siklus I kemudian pada siklus II mengalami peningkatan sebesar 10,21 sehingga menjadi 88,54 dengan katagori sangat baik. Di samping itu, ketuntasan belajar mengalami peningkatan sebesar $31,25 \%$ dari $65,63 \%$ menjadi $96,88 \%$. Berdasarkan hasil tersebut, maka dapat disimpulkan penggunaan metode eksperimen berbantuan media konkret dapat meningkatkan hasil belajar IPA siswa kelas IV SD Negeri 1 Seraya Barat semester ganjil tahun pelajaran 2019/2020.

\section{Pendahuluan}

Perkembangan teknologi tidak akan lepas dari perkembangan dalam bidang IPA. Perkembangan dari bidang IPA tidak mungkin terjadi bila tidak disertai dengan peningkatan mutu pendidikan IPA, sedangkan selama ini muatan pelajaran IPA dianggap sebagai pelajaran yang sulit. Hal ini dapat dilihat dari muatan pelajaran IPA yang ratarata masih rendah bila dibandingkan dengan pelajaran lainnya. Ini Menunjukkan masih rendahnya mutu pelajaran IPA.

Disamping keterlibatan siswa yang minim, pembelajaran yang sudah diterapkan oleh guru selama ini membuat siswa lekas bosan terhadap IPA dan cenderung enggan untuk tahu lebih banyak karena siswa hanya tinggal menunggu apa yang akan ditulis guru didepan kelas dan siswa akan menyalin kedalam catatannya. Dengan kata lain, siswa kurang tertarik terhadap pelajaran, sehingga apa yang disampaikan oleh gurunya pada saat pembelajaran akan cepat dilupakan siswa karena pendalaman konsep tidak ada, pemahaman kurang, dan siswa tidak mendapatkan kesempatan menggali sendiri apa yang ingin atau harus dia ketahui.

Secara empiris untuk semester Ganjil tahun pelajaran 2019/2020 hasil belajar muatan pelajaran IPA siswa Satuan Pendidikan SD Negeri 1 Seraya Barat, khususnya 
kelas IV (kelas binaan penulis) secara rata-rata selalu berada di bawah KBM (68). Dilihat dari hasil tersebut sangat jelas bahwa hasil belajar siswa dalam bidang IPA masih belum cukup karena belum mencapai target yang telah ditetapkan sekolah. Kurang memuaskannya hasil belajar siswa dalam bidang IPA dipengaruhi oleh berbagai faktor yang satu diantaranya adalah aktivitas siswa dalam mengikuti pelajaran IPA (Suryabrata (1995:250-254). Rendahnya hasil belajar juga disebabkan karena dalam pembelajaran aktifitas guru lebih menonjol bila dibandingkan dengan aktifitas murid terutama, guru kurang variatif dalam mengelola pembelajaran. Pembelajaran di kelas masih banyak dilakukan dengan menempatkan siswa sebagai pendengar sehingga mereka cenderung pasif dan kurang bergairah dalam mengikuti pembelajaran di kelasnya. Hal ini sangat mungkin karena guru tidak menggunakan metode pembelajaran yang menarik dalam pembelajaran IPA di kelasnya.

Berangkat dari pernyataan di atas, perlu ditemukan cara terbaik dalam pembelajaran guna menyampaikan konsep materi kepada peserta didik. Yang ingin diharapkan adalah meningkatnya hasil belajar. Ketidakberhasilan peserta didik kelas IV dalam pembelajaran IPA dikarenakan guru belum menggunakan metode pembelajaran yang tepat dalam kegiatan belajar mengajar. Proses pembelajaran kurang kondusif karena banyak menggunakan metode ceramah. Peneliti harus segera melakukan tindakan untuk memperbaiki ketidakberhasilan tersebut dengan membangkitkan minat belajar peserta didik pada proses pembelajaran IPA dengan menggunakan metode eksperimen berbantuan media konkret. Hal ini sangat penting karena diharapkan dengan menggunakan metode eksperimen berbantuan media konkret hasil belajar IPA dapat meningkat. Penulis mencoba memperbaiki pembelajaran IPA agar menjadi menarik, bervariasi, menyenangkan, dan bermakna bagi peserta didik dengan melakukan tindakan melalui penggunaan metode eksperimen berbantuan media konkret.

\section{Metode}

\section{Jenis Penelitian}

Jenis penelitian yang dilakukan adalah penelitian tindakan kelas (Classroom Action Research) yang secara umum bertujuan meningkatkan dan memperbaiki kualitas proses pembelajaran di kelas tempat berlangsungnya penelitian. Tindakan yang dilakukan dalam penelitian ini adalah penggunaan metode eksperimen berbantuan media konkret. Penelitian ini dilaksanakan pada suatu kelas yang mempunyai masalah pembelajaran. 


\section{Subjek dan Objek Penelitian}

Subjek penelitian ini adalah siswa Kelas IV Satuan Pendidikan SD Negeri 1 Seraya Barat semester ganjil tahun pelajaran 2019/2020, dengan jumlah siswa 32 orang, jumlah siswa laki-laki 24 orang dan perempuan 8 siswa. Objek dari penelitian tindakan kelas ini adalah hasil belajar muatan mata pelajaran IPA siswa Kelas IV Satuan Pendidikan SD Negeri 1 Seraya Barat semester ganjil tahun Pelajaran 2019/2020 setelah penggunaan metode eksperimen berbantuan media konkret. Adapun istilah yang digunakan antara lain:Hasil belajar adalah kemampuan-kemampuan yang dimiliki siswa setelah ia menerima pengalaman belajarnya. Secara operasional yang dimaksud dengan hasil belajar IPA dalam penelitian ini adalah kemampuan-kemampuan yang dimiliki oleh siswa setelah dipelajari melalui kegiatan belajar mengajar di kelas. Hasil belajar muatan mata pelajaran IPA siswa dapat diukur melalui tes sebagai alat penilaian.

\section{Prosedur Penelitian Tindakan}

Penelitian ini dibagi dalam dua siklus dengan masing-masing siklus terdiri dari empat tahapan yaitu: 1) perencanaan, 2) tindakan, 3) observasi/evaluasi, dan 4) refleksi. Desain penelitian ini dapat digambarkan seperti Gambar 1 berikut :
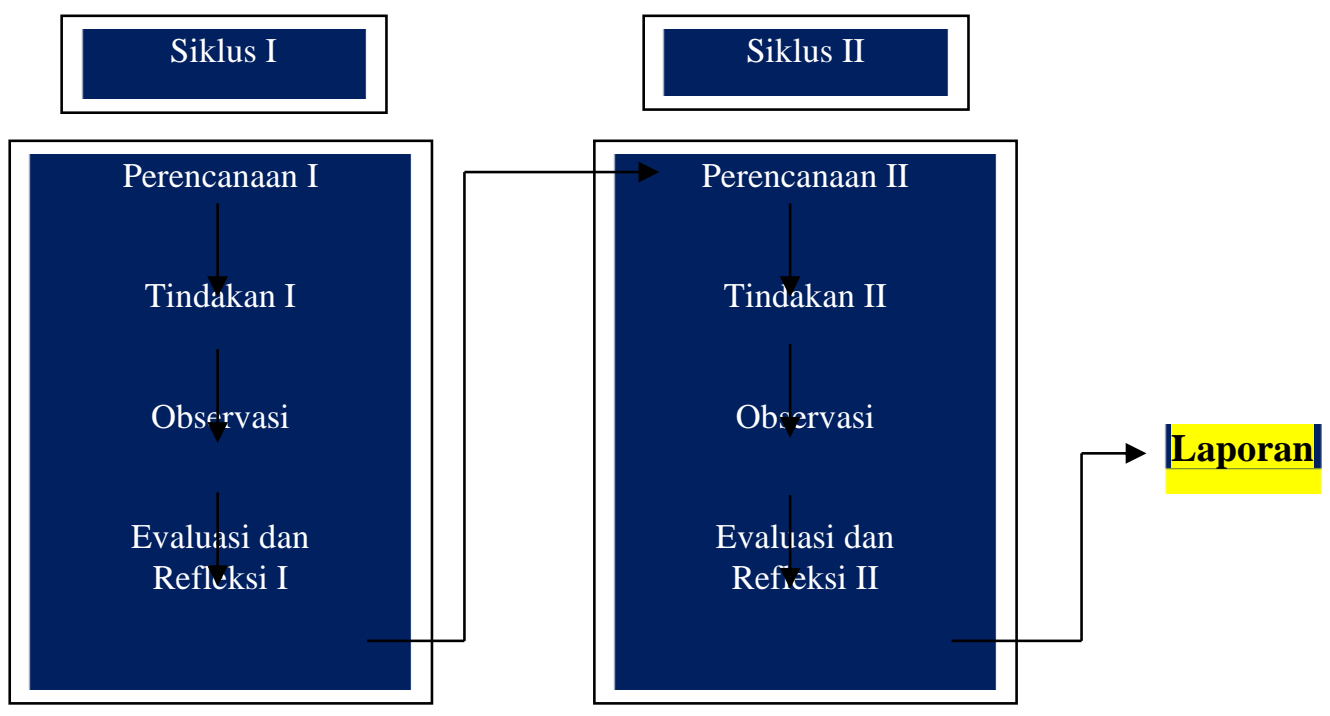

(Agung,2000)

Gambar 1. Tahapan dalam Siklus Penelitian

Penelitian ini menggunakan model proses yang berkesinambungan, mulai dari proses penelitian siklus ke-1, ditindaklanjuti proses penelitian siklus ke-2. Prosedur penelitian tindakan kelas ini setiap siklus meliputi kegiatan: 

a. Perencanaan/persiapan (planning),
b. Pelaksanaan tindakan (acting),
c. Observasi (observing)
d. Refleksi (reflecting

\section{Pengumpulan Data}

Data-data yang dikumpulkan dalam penelitian ini adalah hasil belajar IPA dengan tes evaluasi berupa tes essay atau uraian sebanyak 5 soal, dan skor maksimal 100. Jenis instrumen dan teknik pengumpulan data terlihat pada tabel 1 sebagai berikut :

Tabel 1. Instrumen dan Teknik Pengumpulan Data

\begin{tabular}{|l|l|l|l|}
\hline \multicolumn{1}{|c|}{ Jenis Data } & Metode & Pengumpulan Data & \multicolumn{2}{|c|}{ Waktu Pelaksanaan } \\
\hline Hasil Belajar & Tes & Tes Essay/Uraian & $\begin{array}{l}\text { Akhir siklus I dan } \\
\text { akhir siklus II }\end{array}$ \\
\hline
\end{tabular}

\section{Teknik Analisis Data}

Analisis data dalam penelitian tindakan kelas bertujuan untuk memperoleh data berupa tes hasil belajar yang diberikan pada siswa di setiap siklus apakah terjadi perbaikan atau peningkatan terutama pada materi bunyi muatan pelajaran IPA sebagaimana yang diharapkan yang kemudian dianalisis.

Tes untuk mengukur hasil belajar siswa pada materi bunyi dilakukan pada setiap pertemuan ditiap siklusnya. Data yang diperoleh dari hasil tes siswa dianalisis untuk mengetahui seberapa besar peningkatan hasil belajar dengan penggunaan metode eksperimen berbatuan media konkret melihat ketuntasan belajarnya. Hasil tes belajar siswa pada akhir siklus juga dihitung nilai rata-ratanya. Hasil tes pada akhir siklus I dibandingkan dengan siklus II dan seterusnya. Jika mengalami kenaikan maka diasumsikan melalui penggunaan metode eksperimen berbatuan media konkret dapat meningkatkan hasil belajar siswa pada materi bunyi.

Rubrik penilaian :

a. Jika siswa menjawab soal dengan benar, tepat dan lengkap skor $=3$

b. Jika siswa menjawab benar dan singkat skor $=2$

c. Jika siswa menjawab singkat namun salah skor $=1$

d. Jika siswa tidak menjawab skor $=0$ 
Untuk menghitung ketuntasan belajar siswa menggunakan rumus:

$$
\mathrm{NP}=\frac{\mathrm{R}}{\mathrm{SM}} \times 100
$$

(Ngalim Purwanto, 2010)

Keterangan:

NP

$=$ nilai persen yang dicari atau diharapkan

$\mathrm{R}$

$=$ skor mentah yang diperoleh siswa

SM

= skor maksimum ideal dari tes yang bersangkutan

100

= bilangan tetap

Untuk menghitung persentase ketuntasan belajar siswa menggunakan rumus:

$$
\mathrm{KB}=\frac{\mathrm{T}}{\mathrm{Tt}} \times 100 \%
$$

Adapun kategori tingkat predikat dalam penelitian ini seperti tabel 2.

Tabel 2. Predikat Pencapaian Hasil Belajar

\begin{tabular}{|c|c|c|c|}
\hline $\begin{array}{l}\text { Tingkat Predikat } \\
\%\end{array}$ & Nilai Huruf & Bobot & Predikat \\
\hline & & & \\
$86-100$ & A & 4 & Sangat Baik \\
$76-85$ & B & 3 & Baik \\
$60-75$ & C & 2 & Cukup \\
$55-59$ & D & 1 & Kurang \\
$\leq 54$ & TL & 0 & Kurang Sekali \\
\hline
\end{tabular}

\section{Kriteria Keberhasilan}

Siswa dikatakan tuntas jika $\bar{X} \geq 68$ dan satu kelas dikatakan tuntas jika KK $\geq$ 85\%. Hal ini sesuai dengan yang ditetapkan oleh Satuan Pendidikan SD Negeri 1 Seraya Barat pada semester ini.

Peningkatan pada aspek hasil belajar IPA siswa dianalisis dengan rata-rata skor yang diperoleh oleh siswa dalam satu kelas $(\bar{X})$ pada siklus I dibandingkan dengan ratarata yang diperoleh siswa pada siklus II. Aspek hasil belajar IPA siswa dikatakan meningkat jika rata-rata nilai hasil belajar IPA siswa siklus II lebih besar dari rata-rata siklus I. 


\section{Hasil Dan Pembahasan}

Penelitian ini dilaksanakan dalam waktu 3 bulan dari bulan Agustus s/d Nopember 2019. Penelitian tindakan kelas ini dilaksanakan di kelas IV Satuan Pendidikan SD Negeri 1 Seraya Barat, Sekolah Dasar ini merupakan salah satu sekolah yang berada di kabupaten Karangasem. Tepatnya berada di Br Dinas Bungkulan, desa Seraya Barat Kecamatan Karangasem, Kabupaten Karangasem. Satuan Pendidikan SD Negeri 1 Seraya Barat merupakan salah satu sekolah imbas di Kecamatan Karangasem yang bernaung di Gugus VIII Kecamatan Karangasem. Pembelajaran yang terjadi di Satuan Pendidikan SD Negeri 1 Seraya Barat sudah cukup baik hanya mungkin keadaan fasilitas dan guru yang ada beberapa kurang berkompetensi dalam pemberian pembelajaran. Minimnya media dan sumber belajar dalam melaksanakan kegiatan belajar mengajar setiap hari, sehingga kadang murid kurang bisa dalam menangkap apa yang diberikan oleh guru. Apalagi bagi anak SD harus diajarkan dengan metode-metode maupun model yang bervariasi agar mereka semakin termotivasi dalam belajar.

Berdasarkan pengamatan di lapangan, proses pembelajaran kelas IV di Satuan Pendidikan SD Negeri 1 Seraya Barat masih berpusat pada guru sehingga belum mampu membangkitkan budaya belajar pada diri siswa. Tenaga pendidik masih menggunakan model pembelajaran konvensional secara monoton dalam kegiatan pembelajaran di kelas, sehingga suasana belajar terkesan kaku dan didominasi oleh sang guru. Siswa kurang mampu mengembangkan pembelajaran sesuai dengan konteks kehidupan disekitarnya serta kurangnya sumber belajar siswa karena hanya berpaku pada buku paket yang siswa miliki. Hasilnya dalam muatan mata pelajaran IPA yang dicapai belum maksimal. Membangkitkan hasil belajar peserta didik mengikuti proses pembelajaran, melalui penggunaan metode pembelajaran eksperimen berbantuan media konkret.

Hal penting dari suatu penelitian adalah akan dikembangkan suatu hal (model, pendekatan, alat peraga) yang diharapkan mampu mengatasi masalah pembelajaran yang ada. Rencana tindakan di atas berpedoman pada rencana pembelajaran dengan langkahlangkah perbaikan pembelajaran yang dilaksanakan dalam 2 siklus.

\section{Deskripsi Hasil Penelitian}

a. Hasil Refleksi Awal

Refleksi awal yang dilakukan peneliti hanya sebatas terhadap tes hasil belajar IPA dengan memberikan siswa 5 butir soal uraian dan hasil menunjukkan data sebagai berikut. 
Tabel 3. Hasil Penelitian Pada Pra Siklus

\begin{tabular}{|c|c|c|c|}
\hline No & Tingkat Predikat & Frekuensi & Persentase \\
\hline 1 & Baik Sekali & 2 & $6,25 \%$ \\
\hline 2 & Baik & 8 & $25,00 \%$ \\
\hline 3 & Cukup & 10 & $31,25 \%$ \\
\hline 4 & Kurang & 0 & $0,00 \%$ \\
\hline 5 & Kurang Sekali & 12 & $37,50 \%$ \\
\hline \multicolumn{3}{|c|}{ Rata-rata } & 65,21 \\
\hline \multicolumn{3}{|c|}{ Ketuntasan Klasikal } & $43,75 \%$ \\
\hline
\end{tabular}

Berdasarkan tabel di atas menunjukkan, hasil bahwa secara klasikal, ketuntasan belajar siswa hanya mencapai $43,75 \%$. Hal ini menunjukkan bahwa hasil belajar muatan pelajaran IPA siswa kelas IV Satuan Pendidikan SD Negeri 1 Seraya Barat rendah. Sementara itu, rata-rata siswa adalah sebesar 65,21 dan daya serap siswa terhadap pembelajaran IPA dalam materi bunyi hanya $65,21 \%$. Setelah dilakukan observasi lebih lanjut,dipandang perlu dilaksanakan tindakan untuk memperbaiki hasil belajar IPA siswa. Tindakan tersebut adalah dengan mengujicobakan Metode eksperimen berbantuan media konkret.

b. Deskripsi Siklus I

Perbaikan pembelajaran siklus I merupakan usaha perbaikan pembelajaran dari hasil yang dicapai pada pembelajaran yang dilaksanakan sebelumnya. Perbaikan pembelajaran pada siklus I ini melakukan tindakan dengan menggunakan metode pembelajaran "Eksperimen berbantuan Media Konkret". Pada tindakan siklus I ini, guru sebagai peneliti dan pelaksana pembelajaran, terlebih dahulu menyusun perencanaan tindakan, pelaksanaan tindakan, hasil pengamatan, dan refleksi. Pada pertemuan ke 3, siswa dievaluasi dengan cara memberikan tes uraian yang berisi 5 butir soal. Hasil evaluasi terhadap hasil belajar siswa kelas IV Satuan Pendidikan SD Negeri 1 Seraya Barat dalam muatan pelajaran IPA materi bunyi dapat dilihat pada tabel berikut.

Tabel 4. Hasil penelitian siklus I

\begin{tabular}{|c|c|c|c|}
\hline No & Tingkat Predikat & Frekuensi & Persentase \\
\hline 1 & Baik Sekali & 10 & $31,25 \%$ \\
\hline 2 & Baik & 6 & $18,75 \%$ \\
\hline 3 & Cukup & 13 & $40,63 \%$ \\
\hline 4 & Kurang & 0 & $0,00 \%$ \\
\hline 5 & Kurang Sekali & 3 & $9,38 \%$ \\
\hline \multicolumn{3}{|c|}{ Rata-rata } & 78,33 \\
\hline \multicolumn{3}{|c|}{ Ketuntasan Klasikal } & $65,63 \%$ \\
\hline
\end{tabular}


Tabel di atas menunjukkan adanya peningkatan hasil belajar siswa dibandingkan dari hasil relfleksi awal. Sejumlah 21 siswa dari 32 siswa atau 65,63\% sudah mencapai Ketuntasan Belajar Minimal (KBM) dengan nilai rata-rata kelas 78,33 Hasil tes siklus I mendapat tingkat predikat "baik" dan pembelajaran belum dikatakan berhasil karena belum memenuhi kriteria keberhasilan pembelajaran yaitu apabila terdapat $85 \%$ dari keseluruhan siswa telah mencapai nilai KBM sebesar 68.

Perbandingan hasil belajar, daya serap, dan ketuntasan klasikal siswa pada pretest dan siklus I dapat dilihat pada grafik berikut.

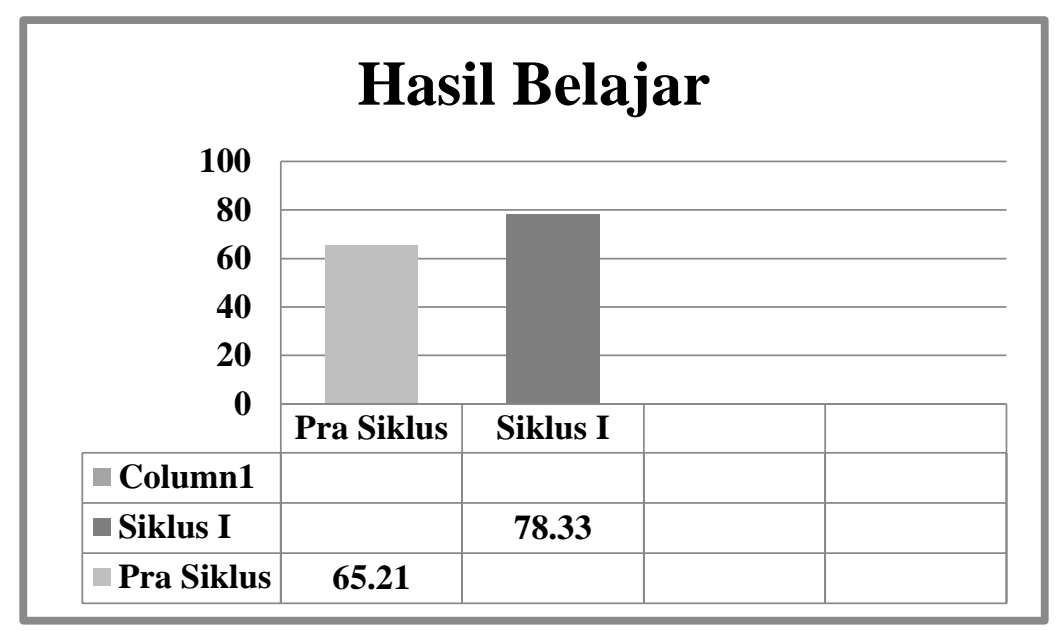

Grafik 1. Hasil Belajar Siswa Siklus I

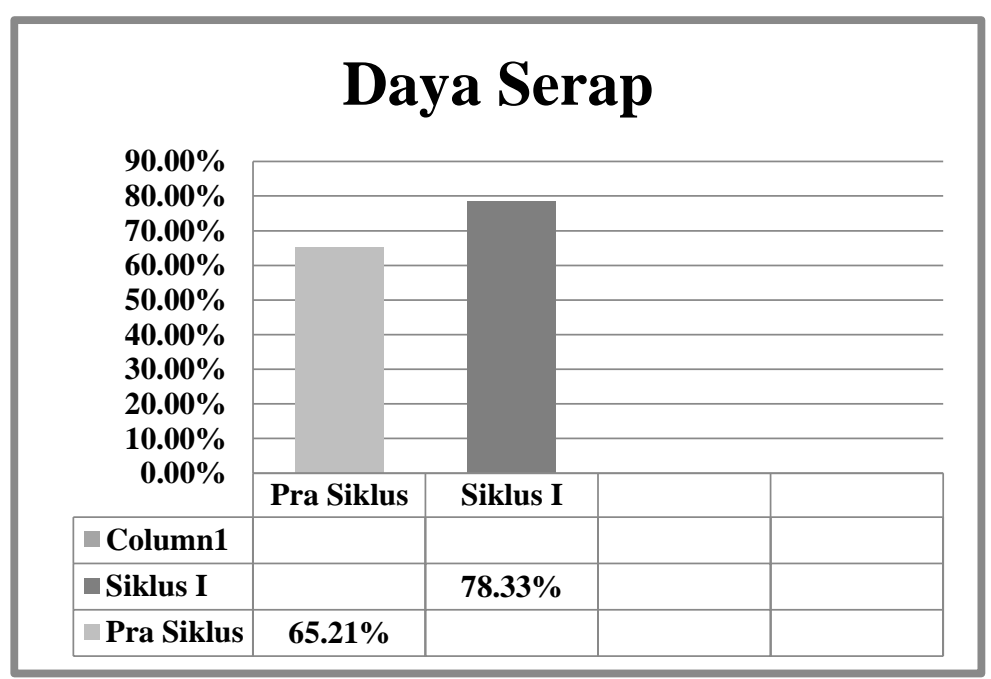

Grafik 2. Daya Serap Siswa Siklus I 


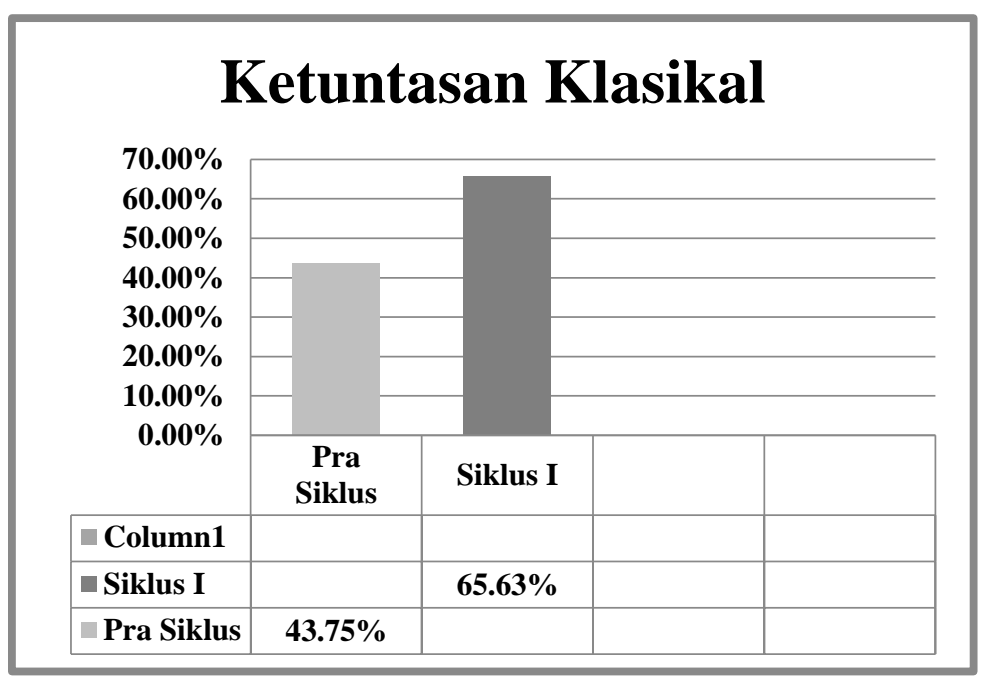

Grafik 3. Ketuntasan Klasikal Siswa Siklus I

\section{Refleksi Siklus I}

Tabel 5. Perbandingan Tindakan Refleksi Awal dengan Siklus I

\begin{tabular}{|l|l|l|l|l|}
\hline No & Uraian & \multicolumn{1}{|c|}{ Refleksi Awal } & \multicolumn{1}{|c|}{ Siklus I } & Refleksi \\
\hline 1 & Tindakan & $\begin{array}{l}\text { Dalam } \\
\text { pembelajaran IPA } \\
\text { bunyi belum } \\
\text { menggunakan } \\
\text { metode pembelajan } \\
\text { "Eksperimen } \\
\text { berbantuan Media } \\
\text { Konkret" }\end{array}$ & $\begin{array}{l}\text { Dalam pembelajaran IPA } \\
\text { materi bunyi } \\
\text { menggunakan metode } \\
\text { pembelajaran "Eksperimen } \\
\text { berbantuan Media } \\
\text { Konkret" oleh siswa secara } \\
\text { kelompok,guru } \\
\text { membimbing secara } \\
\text { menyeluruh didepan kelas }\end{array}$ & \\
\hline
\end{tabular}

Tabel 6. Perbandingan Proses Pembelajaran Refleksi dengan Siklus I

\begin{tabular}{|c|c|c|c|c|}
\hline No & Uraian & Refleksi Awal & Siklus I & Refleksi \\
\hline 2 & $\begin{array}{l}\text { Proses } \\
\text { Pembelajaran }\end{array}$ & $\begin{array}{l}\text { siswa yang } \\
\text { belum berminat } \\
\text { mengikuti } \\
\text { pembelajaran, } \\
\text { siswa masih } \\
\text { berpaku pada } \\
\text { buku paket, } \\
\text { dan siswa } \\
\text { kurang aktif } \\
\text { dalam } \\
\text { pembelajaran }\end{array}$ & $\begin{array}{l}\text { peserta didik yang } \\
\text { kurang berminat } \\
\text { makin berkurang, } \\
\text { siswa mulai aktif } \\
\text { melakukan } \\
\text { eksperimen } \\
\text { berbantuan } \\
\text { media konkret } \\
\text { sebagai alat } \\
\text { peraga dan } \\
\text { sumber belajar } \\
\text { siswa sudah mulai } \\
\text { bervariasi }\end{array}$ & $\begin{array}{l}\text { Terdapat keaktifan } \\
\text { peserta didik dalam } \\
\text { pembelajaran, hasil } \\
\text { belajar peserta didik } \\
\text { sudah meningkat,tetapi } \\
\text { belum maksimal karena } \\
\text { masih ada siswa kurang } \\
\text { aktif dalam kelompoknya. } \\
\text { Hal ini disebabkan guru } \\
\text { belum memberikan } \\
\text { bimbingan ke masing- } \\
\text { masing kelompok dalam } \\
\text { percobaan }\end{array}$ \\
\hline
\end{tabular}


Tabel 7. Perbandingan Hasil Belajar Refleksi Awal dengan Siklus I

\begin{tabular}{|c|l|l|l|l|}
\hline No & Uraian & \multicolumn{1}{|c|}{ Refleksi Awal } & \multicolumn{1}{c|}{ Siklus I } & \multicolumn{1}{c|}{ Refleksi } \\
\hline 3 & Hasil & Hasil Evaluasi pada & Hasil Evaluasi & Nilai terendah \\
& Belajar & kondisi awal nilai & pada Siklus 1 & meningkat dari 26,7 \\
& & terendah 26,7 nilai & nilai terendah & menjadi 53,3, nilai \\
& & tertinggi 93,3 nilai & 53,3 nilai & tertinggi dari 93,3 \\
& & Rata-rata 65,21 & tertinggi 100 & meningkat menjadi \\
& & nilai rerata & 100, nilai rata-rata \\
& & 78,33 & meningkat dari 65,21 \\
& & & & \\
\hline
\end{tabular}

\section{Deskripsi Siklus II}

a. Hasil Pengamatan

1) Hasil Pengamatan pada Proses Pembelajaran

Proses pembelajaran yang terjadi pada siklus II menunjukkan adanya suatu perubahan tingkah laku peserta didik saat mengikuti kegiatan pembelajaran. Peserta didik sangat aktif dalam kerja kelompok serta siswa sudah berani mengemukakan pendapat dalam penggunaan metode pembelajaran "Eksperimen berbantuan media konkret". Peserta didik banyak yang berminat dalam mengikuti pembelajaran karena dibimbing langsung ke masing-masing kelompok.

2) Hasil Pengamatan pada Hasil Pembelajaran

Hasil pembelajaran pada siklus II berupa nilai seperti tertera pada tabel berikut Tabel 8. Hasil Penelitian Siklus II

\begin{tabular}{|c|c|c|c|}
\hline No & Tingkat Predikat & Frekuensi & Persentase \\
\hline 1 & Baik Sekali & 22 & $68,75 \%$ \\
\hline 2 & Baik & 5 & $15,63 \%$ \\
\hline 3 & Cukup & 5 & $15,63 \%$ \\
\hline 4 & Kurang & 0 & $0,00 \%$ \\
\hline 5 & Kurang Sekali & 0 & $0,00 \%$ \\
\hline \multicolumn{3}{|c|}{ Rata-rata } & 88,54 \\
\hline \multicolumn{3}{|c|}{ Ketuntasan Klasikal } & $96,88 \%$ \\
\hline
\end{tabular}

Berdasarkan perhitungan setelah dilaksanakan tindakan pada Siklus II, dapat diperoleh hasil bahwa secara klasikal, ketuntasan belajar siswa sudah bisa mencapai 96,88\%. Hal ini menunjukkan bahwa hasil belajar siswa kelas IV Satuan Pendidikan SD Negeri 1 Seraya Barat Semester ganjil sudah melebihi dari target yang peneliti tetapkan. Sementara itu, rata-rata siswa adalah sebesar 88,54 dan daya serap siswa terhadap mata pelajaran IPA dalam materi bunyi adalah $88,54 \%$, hasil daya serap yang diperoleh siswa 
kelas IV Satuan Pendidikan SD Negeri 1 Seraya Barat Semester ganjil tahun pelajaran 2019/2020 sudah tergolong sangat baik, hasil belajar siswa juga dapat dilihat pada grafik batang berikut :

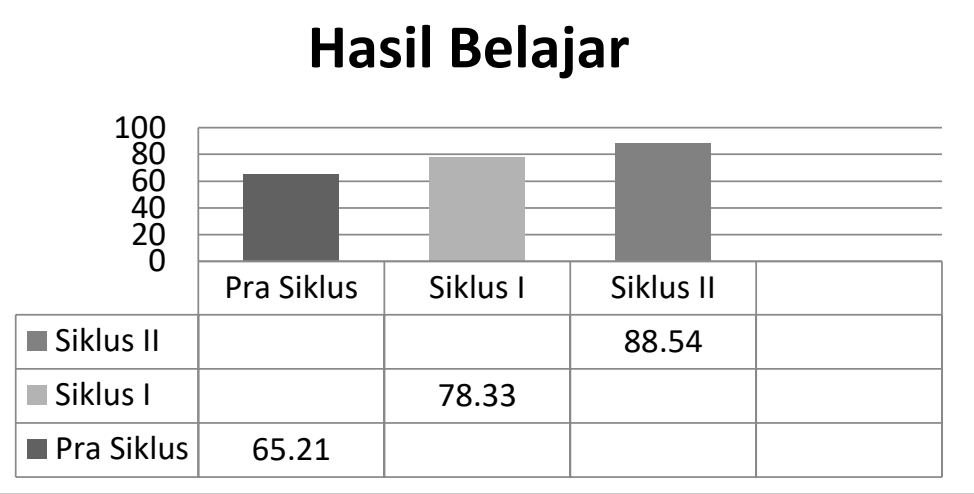

Grafik 4. Hasil Belajar Siswa Siklus II

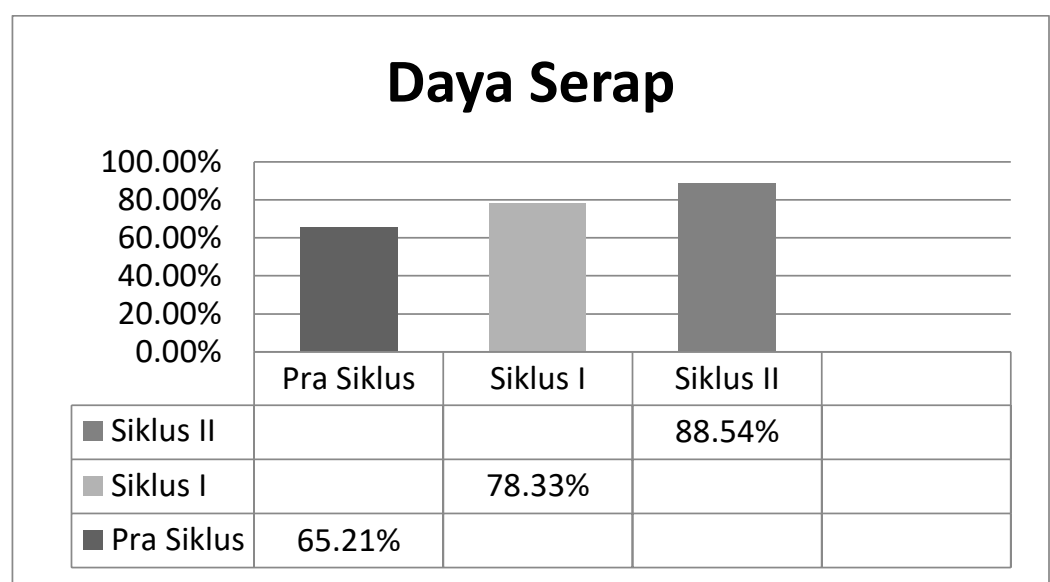

Grafik 5. Daya Serap Siswa Siklus II

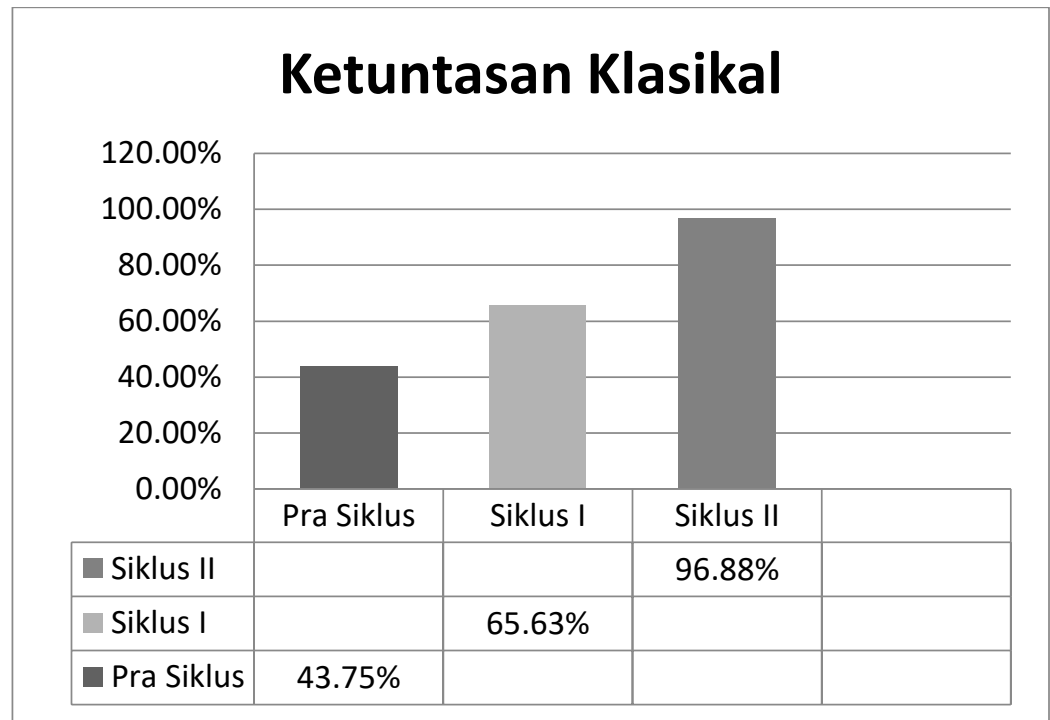

Grafik 6. Ketuntasan Klasikal Siklus II 
b. Refleksi Siklus II

Tabel 9. Perbandingan Tindakan Siklus I dengan Siklus II

\begin{tabular}{|c|c|c|c|c|}
\hline No & Uraian & Siklus I & Siklus II & Refleksi \\
\hline 1 & Tindakan & $\begin{array}{l}\text { Dalam pembelajaran } \\
\text { IPA materi bunyi } \\
\text { sudah menggunakan } \\
\text { metode pembelajaran } \\
\text { "Eksperimen } \\
\text { berbantuan media } \\
\text { konkret" oleh siswa } \\
\text { secara kelompok } \\
\text { dengan dibimbing } \\
\text { guru dari depan kelas }\end{array}$ & $\begin{array}{l}\text { Dalam pembelajaran } \\
\text { materi bunyi sudah } \\
\text { menggunakan metode } \\
\text { pembelajaran } \\
\text { "Eksperimen berbantuan } \\
\text { media konkret" oleh } \\
\text { siswa dalam kelompok } \\
\text { dengan dibimbing } \\
\text { langsung dalam } \\
\text { kelompok oleh guru }\end{array}$ & \\
\hline
\end{tabular}

Tabel 10. Perbandingan Proses Pembelajaran Siklus I dengan Siklus II

\begin{tabular}{|c|c|c|c|c|}
\hline No & Uraian & Siklus I & Siklus II & Refleksi \\
\hline 2 & $\begin{array}{l}\text { Proses } \\
\text { Pembelajaran }\end{array}$ & $\begin{array}{l}\text { peserta didik yang } \\
\text { kurang berminat } \\
\text { makin berkurang, } \\
\text { siswa mulai aktif } \\
\text { melakukan } \\
\text { eksperimen yang } \\
\text { mengunakan media } \\
\text { konkret sebagai alat } \\
\text { peraga dan sumber } \\
\text { belajar siswa sudah } \\
\text { mulai bervariasi }\end{array}$ & $\begin{array}{l}\text { peserta didik sangat } \\
\text { berminat, siswa } \\
\text { aktif dalam } \\
\text { kelompok, siswa } \\
\text { sangat } \\
\text { memperhatikan } \\
\text { bimbingan guru } \\
\text { dalam mengerjakan } \\
\text { LKS, melalui } \\
\text { eksperimen sumber } \\
\text { belajar siswa sudah } \\
\text { bervariasi }\end{array}$ & $\begin{array}{l}\text { peserta didik } \\
\text { sebagian besar } \\
\text { aktif dan } \\
\text { berminat dalam } \\
\text { pembelajaran, } \\
\text { hasil belajar } \\
\text { peserta didik } \\
\text { sudah } \\
\text { meningkat }\end{array}$ \\
\hline
\end{tabular}

Tabel 11. Perbandingan Hasil Belajar Siklus I dengan Siklus II

\begin{tabular}{|c|c|c|c|c|}
\hline No & Uraian & Siklus I & Siklus II & Refleksi \\
\hline 3 & $\begin{array}{l}\text { Hasil } \\
\text { Belajar }\end{array}$ & $\begin{array}{l}\text { Hasil Evaluasi pada } \\
\text { Siklus I nilai } \\
\text { terendah } 53,3 \text { nilai } \\
\text { tertinggi } 100 \text { nilai } \\
\text { rata-rata } 78,33\end{array}$ & $\begin{array}{l}\text { Hasil Evaluasi pada } \\
\text { Siklus II nilai } \\
\text { terendah } 60,00 \text { nilai } \\
\text { tertinggi } 100 \text { nilai } \\
\text { rata-rata } 88,54\end{array}$ & $\begin{array}{l}\text { Nilai terendah } \\
\text { meningkat dari } 53,3 \\
\text { menjadi } 60,00 \text {, nilai } \\
\text { tertinggi tetap } \\
\text { dengan nilai } 100 \text { dan } \\
\text { rata-rata meningkat } \\
\text { dari } 78,33 \text { menjadi } \\
88,54\end{array}$ \\
\hline
\end{tabular}




\section{Pembahasan Antar dan Tiap Siklus}

Pembahasan penelitian ini didasarkan pada proses dan hasil pelaksanaan tindakan kelas yang dilakukan dalam siklus tindakan. Penelitian ini bertujuan untuk mengetahui peningkatan hasil belajar IPA pada siswa kelas IV melalui penggunaan metode eksperimen berbantuan media konkret . Hasil belajar meliputi tiga aspek, yaitu; Tindakan, Proses Belajar, dan Hasil Belajar. Ketiga aspek tersebut mengalami peningkatan pada kondisi awal, siklus I, dan siklus II.

a. Tindakan

Tabel 12. Perbandingan Tindakan Refleksi Awal, Siklus I, dan Siklus II

\begin{tabular}{|c|c|c|c|}
\hline No & Refleksi Awal & Siklus I & Siklus II \\
\hline 1 & $\begin{array}{l}\text { Dalam pembelajaran } \\
\text { IPA bunyi belum } \\
\text { menggunakan metode } \\
\text { pembelajaran } \\
\text { "Eksperimen } \\
\text { berbantuan media } \\
\text { konkret" }\end{array}$ & $\begin{array}{l}\text { Dalam pembelajaran } \\
\text { IPA materi bunyi } \\
\text { sudah menggunakan } \\
\text { metode } \\
\text { pembelajaran } \\
\text { "Eksperimen } \\
\text { berbantuan media } \\
\text { konkret" oleh siswa } \\
\text { secara kelompok } \\
\text { dengan langkah- } \\
\text { langkah pada LKS }\end{array}$ & $\begin{array}{l}\text { Dalam pembelajaran IPA } \\
\text { materi bunyi sudah } \\
\text { menggunakan metode } \\
\text { pembelajaran "Eksperimen } \\
\text { berbantuan media konkret" } \\
\text { oleh siswa secara } \\
\text { kelompok dengan langkah- } \\
\text { langkah pada LKS dan } \\
\text { bimbingan langsung dari } \\
\text { guru ke masing-masing } \\
\text { kelompok. }\end{array}$ \\
\hline
\end{tabular}

\section{b. Proses Pembelajaran}

Tabel 12. Perbandingan Proses Pembelajaran Refleksi Awal, Siklus I, dan Siklus II

\begin{tabular}{|c|c|c|c|c|}
\hline No & Kondisi Awal & Siklus I & $\begin{array}{l}\text { Siklus IV/ } \\
\text { Kondisi akhir }\end{array}$ & $\begin{array}{c}\text { Refleksi dari } \\
\text { Refleksi awal } \\
\text { Sampai Siklus } \\
\text { II }\end{array}$ \\
\hline 2 & $\begin{array}{l}\text { siswa yang } \\
\text { belum berminat } \\
\text { mengikuti } \\
\text { pembelajaran, } \\
\text { siswa masih } \\
\text { berpaku pada } \\
\text { buku paket, dan } \\
\text { siswa kurang } \\
\text { aktif dalam } \\
\text { pembelajaran }\end{array}$ & $\begin{array}{l}\text { peserta didik yang } \\
\text { kurang berminat } \\
\text { makin berkurang, } \\
\text { siswa mulai aktif } \\
\text { dalam mengikuti } \\
\text { pelajaran dengan } \\
\text { media konkret } \\
\text { yang disediakan } \\
\text { guru dan melalui } \\
\text { eksperimen sumber } \\
\text { belajar siswa sudah } \\
\text { mulai bervariasi }\end{array}$ & $\begin{array}{l}\text { peserta didik } \\
\text { sangat berminat, } \\
\text { siswa aktif dalam } \\
\text { kelompok, siswa } \\
\text { sangat } \\
\text { memperhatikan } \\
\text { pelajaran karena } \\
\text { bimbingan } \\
\text { langsung dari guru, } \\
\text { melalui eksperimen } \\
\text { berbantuan media } \\
\text { konkret sumber } \\
\text { belajar siswa sudah } \\
\text { bervariasi }\end{array}$ & $\begin{array}{l}\text { Dari kondisi } \\
\text { awal ke kondisi } \\
\text { akhir terdapat } \\
\text { peningkatan } \\
\text { minat dan } \\
\text { aktifitas peserta } \\
\text { didik dalam } \\
\text { proses } \\
\text { pembelajaran } \\
\text { IPA }\end{array}$ \\
\hline
\end{tabular}




\section{c. Hasil Belajar}

Tabel 13. Perbandingan Hasil Belajar Refleksi Awal, Siklus I, dan Siklus II

\begin{tabular}{|c|c|c|c|c|}
\hline No & Refleksi Awal & Siklus I & Siklus II & $\begin{array}{c}\text { Refleksi dari } \\
\text { Refleksi awal } \\
\text { sampai Ke Siklus II }\end{array}$ \\
\hline 3 & $\begin{array}{l}\text { Hasil Evaluasi } \\
\text { pada kondisi } \\
\text { awal nilai } \\
\text { terendah } 26,7 \\
\text { nilai tertinggi } \\
93,3 \text { nilai } \\
\text { Rata-rata } 65,21\end{array}$ & $\begin{array}{l}\text { Hasil Evaluasi } \\
\text { pada Siklus I } \\
\text { nilai terendah } \\
53,3 \text { nilai } \\
\text { tertinggi } 100 \\
\text { nilai rata-rata } \\
78,33\end{array}$ & $\begin{array}{l}\text { Hasil Evaluasi } \\
\text { pada Siklus II } \\
\text { nilai terendah } \\
60,00 \text { nilai } \\
\text { tertinggi } 100 \\
\text { nilai rata-rata } \\
88,54\end{array}$ & $\begin{array}{l}\text { Dari Refleksi awal } \\
\text { sampai pada Siklus } \\
\text { II terdapat } \\
\text { peningkatan hasil } \\
\text { belajar dari rata-rata } \\
65,21 \text { menjadi } 88,54\end{array}$ \\
\hline
\end{tabular}

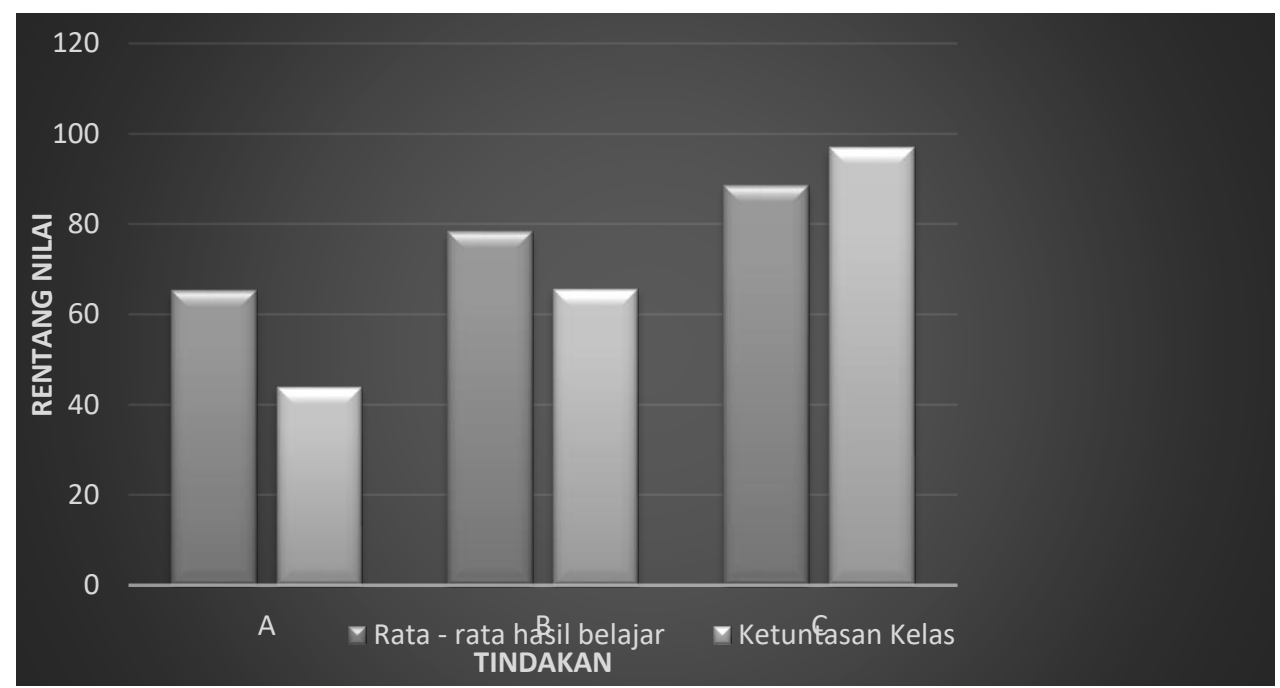

Grafik 7. Rata-Rata Hasil Belajar dan Ketuntasan kelas Siswa Pada Refleksi Awal, Siklus I dan Siklus II

Keterangan :
A. : Pra Siklus
B. : Siklus I
C. : $\quad$ Siklus II

\section{Kesimpulan}

Berdasarkan pelaksanaan penelitian dapat disimpulkan bahwa penggunaan metode pembelajaran eksperimen berbantuan media konkret dapat meningkatkan hasil belajar IPA materi bunyi pada siswa kelas IV SD Negeri 1 Seraya Barat kecamatan Karangasem, Kabupaten Karangasem. Metode pembelajaran "eksperimen berbantuan media konkret"berpengaruh dalam hal-hal sebagai berikut. 
1. Meningkatkan minat, aktifitas, dan antusias peserta didik sehingga hasil belajar dapat meningkat;

2. Meningkatkan keefektifan waktu, sehingga tidak banyak waktu yang terbuang;

3. Dalam proses pembelajaran, peserta didik merasa senang dan berminat.

Penggunaan metode pembelajaran eksperimen berbantuan media konkret meningkatkan hasil belajar IPA khusunya materi bunyi, karena :

1. Merupakan variasi dalam pembelajaran sehingga peserta didik tidak hanya mendengarkan dan melihat peragaan, tapi langsung mencoba sendiri untuk menemukan jawaban.

2. Dengan penggunaan metode pembelajaran eksperimen berbantuan media konkret, peserta didik dapat menemukan cara belajar baru pada materi bunyi.

Jadi berdasarkan pengamatan penelitian membuktikan bahwa melalui penggunaan metode pembelajaran "Eksperimen berbantuan media konkret" dapat meningkatkan hasil belajar muatan mata pelajaran IPA pada siswa kelas IV SD Negeri 1 Seraya Barat kecamatan Karangasem kabupaten Karangasem.

\section{Daftar Pustaka}

Abdillah, Isak (2011). Pengaruh Metode Eksperimen Terhadap Hasil Belajar Ranah Psikomotor Siswa Pada Mata Pelajaran Teknik Dua Dimensi Di SMK. Skripsi UPI. Bandung.

Agung, Gregorius. (2000). Membuat Homepage Interaktif Dengan CGI/Perl. Jakarta: PT.Elex Media Koputindo.

Ahmad, Rohani. (1997). Media Intruksional Edukatif. Jakarta :Rineka Cipta. Anoraga, Panji. (1983). Psikologi Kerja. Jakarta: Rhneka Cipta Jakarta.

Arikunto, S. (2010). Penelitian Tindakan Kelas. Jakarta: PT.BumiAksara

Aristo, Rahadi. (2003). Media Pembelajaran. Jakarta : Departemen Pendidikan Nasional. Asra, dkk. (2007). Komputer dan Media Pembelajaran SD. DitjenDikti. Depdiknas. Jakarta

Djamarah, Syaful Bahri. (2000). Prestasi Belajar dan Kompetensi Guru. Surabaya: Usaha Nasional

Engkoswara. (1984). Dasar-Dasar Metodelogi Pengajaran. Jakarta.PT BinaAksara.

Hamalik, Oemar. (2006). Psikologi Belajar dan Mengajar. Bandung: Sinar Baru Algesindo. 
Hamzah B. U et.al. (2007). Pengembangan Intrumen untuk Penelitian. Jakarta : Dilema Press

Heinich, Robert, et. Al. (1996) Instructional media and technologies for learning (5 ed). New Jersey : Simon \&Schuster Company Engelewood Cliffs.

Ibrahim, M., \& Nur, M. (1993). Pengajaran berdasarkan masalah. Surabaya: Unesa Universitas Press.

Nana Sudjana. (2005). Penilaian Hasil Proses Belajar Mengajar. Bandung: PT. Remaja Rosdikarya

Rahadi. (2003). Media Pembelajaran. Jakarta: Depdiknas

Winataputra. (2000). Materi Pokok Strategi Belajar-Mengajar. Jakarta : Universitas Terbuka. 